\title{
EFFECT OF WORK LIFE POLICY, WORK INVOLVEMENT AND CONFLICT OF WORKING FAMILY TO TURNOVER INTENTIONS ON EMPLOYEES
}

\author{
Moh. Abd. Rahmana \\ Siti Maysarohb \\ aIslamic Economics Department, Faculty of Economics and Business, Zainul Hasan \\ Islamic University \\ bFaculty of Economics and Business, Ahmad Dahlan University, Yogyakarta \\ Email: abduraahmanbinauf39@gmail.com ${ }^{\mathrm{a}}$, smysrh61@gmail.com $^{\mathrm{b}}$
}

\begin{abstract}
Introduction: This study aims to determine the effect of Worklife-Policies, Job Involvement, and Work-Family Conflict on Turnover Intention of employees at PT Sinar Bodhi Cipta, Tanjungpinang. This type of research uses quantitative descriptive method. The sample technique used in this study was the distribution of proportion sampling.

Methods: The data analysis method used consisted of testing the quality of the data (validity and reliability). Classic assumption test (normality, heteroscedasticity, multicolonierity, and autocorrelation)

Results: The results obtained can be concluded that the work-life policies, Job Involvement, and Workfamily Conflict variables partially or simultaneously have a positive and significant effect on employee turnover intention at PT Sinar Bodhi Cipta, Tanjungpinang with a $\mathrm{R}$ square contribution of $73.1 \%$.
\end{abstract}

Keyword: Work-life policies, The involvement of work, Workfamily Conflict Teacher guidance

\section{INTRODUCTION}

Progress in a country is a major dream for every nation. This progress is usually seen from the human resources as well as the natural resources that are developing in the country. There are times when a country has abundant natural resources that can be used but lacks human resources who can manage these natural resources which can be utilized as a result.

In this case, human resources are one of the most important things for the progress of a nation, especially for corporate investment. Where when someone wants to establish a company it is very important for him to have human resources or employees who can increase a productivity result for the company. Good and optimal human resources in accordance with the limits of the ability of employees to achieve a company goal in 
accordance with the wishes of the company or in accordance with the market needs of a company according to Anggaryano in 1 .

This form of constraint is in the form of a desire to change jobs (turnover intention) which leads to an employee's decision to leave a job and try to find a better job and promises everything from his previous job Turnover itself is more directed at the ultimate reality faced by an organization or company. in the form of the large number of employees who leave the organization in a certain period of time, while the desire of employees to move (turnover intentions) refers to an end result or it can be said to be an evaluation or observation of an individual about his continuity with the company whether he wants to survive or even chooses to leave the company. which is where the result is still in an employee's mind.

According to Robbins in Roni said that turnover intention itself is turnover is the voluntary and involuntary withdrawal from an organization. Here it explains that turnover itself is an action taken by an employee against an organization to another organization where the employee is not possible to work again in the company which is wanted by many employees where it will be a very big possibility of turnover intention. it will happen. ${ }^{2}$

Where are the factors that often occur or often experience a turnover intention, namely in general, it lies in the age level and education level of a person, both of which can consider the results of the work to be achieved by the company. Besides that, it can also be seen from several other supporting factors that can trigger employees to intend to leave a company, one of which is work-life policies, work involvement, and work-family conflict as the selected variable and seen as having a greater influence on the level of a person's turnover intention. employees. Work-life policies according to Monday Worklife policies are an initial guideline or an initial direction to provide a positive direction in making a decision, be it a tough decision or a light decision. ${ }^{3}$

Apart from work-life policies that affect turnover intention, namely job involvement is also a very important supporting factor in terms of turnover intention where work involvement is a strong milestone in the company.

According to Karetape insid Work-family conflict is a form of conflict between roles where the pressure from the field of work and pressure from the family contradicts each other. This means that it is very difficult to align or equalize both in terms of work in the

\footnotetext{
${ }^{1}$ Roni, F. (2010). Relationship Between Work Involvement and Turnover Intention of Employees of PT. GARDA TRIMITRA UTAMA, JAKARTA, VIII, 146-151.

2 Roni, F. (2010). Relationship Between Work Involvement and Turnover Intention of Employees of PT. GARDA TRIMITRA UTAMA, JAKARTA, VIII, 146-151.

3 Ludiya, H. (2016). THE EFFECT OF WORK LIFE POLICIES, WORK LIFE CONFLICT, JOB STRESS, AND LONELINESS ON TURNOVER INTENTIONS IN A. Journal of Service Management and Marketing, 9 (2), 299-322.
} 
office and in terms of homework. Where these two things can lead to a turnover intention ${ }^{4}$.

Over time, various phenomena that occur at PT. Sinar Bodhi Cipta, Tanjungpinang, namely the level of employee turnover that has increased in the last two years, namely 2016 and in 2017 compared to previous years. It can be seen from the scale of the last two years, which are as follows:

Employee turnover data

\begin{tabular}{|c|c|c|c|c|c|c|c|c|c|c|c|c|c|c|}
\hline \multirow{2}{*}{ Year } & \multirow{10}{*}{ Employees } & \multicolumn{10}{|c|}{ The month } \\
\cline { 3 - 13 } & & 1 & 2 & 3 & 4 & 5 & 6 & 7 & 8 & 9 & 10 & 11 & 12 & Total \\
\hline \multirow{2}{*}{2016} & Sign in & 2 & 2 & 3 & 2 & 0 & 2 & 3 & 2 & 1 & 1 & 2 & 1 & 21 \\
\cline { 2 - 14 } & Exit & 4 & 4 & 4 & 3 & 3 & 4 & 2 & 4 & 3 & 2 & 4 & 4 & 41 \\
\hline \multirow{2}{*}{2017} & Sign in & 2 & 2 & 1 & 1 & 2 & 3 & 0 & 0 & 1 & 2 & 2 & 2 & 18 \\
\cline { 2 - 15 } & Exit & 3 & 3 & 4 & 4 & 3 & 3 & 4 & 4 & 2 & 2 & 3 & 3 & 38 \\
\hline
\end{tabular}

From the table above, it can be seen that the rate of occurrence of an employee turnover is quite high in PT.Sinar Bodhi Cipta, Tanjungpinang, namely 41 people in 2016 and 38 people in 2017 from January to December. Where the data shows that the rate of resignation of an employee is very large and is closely related to the factors that influence an employee to resign from a company within the department, both permanent and contract employees.

For example, Worklife-Policies where many workers feel uncomfortable because their health and safety at work have not been able to provide the best for their employees.

Researchers are interested in conducting a study in which to find out and see the influence of work-life policies, work involvement, and work-family conflict on employee turnover intention with the title "The Effect of Work-life Policies, Job Involvement, and Work- family ConflictTerhada Turnover Intention to Employees of PT.SINAR BODHI CIPTA, Tanjungpinang ".

\section{LITERATURE REVIEW}

\section{Definition of Human Resource Management Work-life Policies}

According to the wisdom inside Work life policy is very important to be defined as an indicator of the basic level of an organization which prioritizes all work more importantly above everything, both in terms of work and others. Where this policy is

\footnotetext{
${ }^{4}$ Erdiana, A., \& Eviana. (2012). The Effect of Work-Family Conflict on Absenteeism and Turnover Intention (a study on Employees of Banking Companies in Malang), 10, 116-133.
} 
included in arranging flexible work schedules and employee leave from previous workplaces. The work-life policy itself is a major milestone in liaising for the company, if the milestone is unable to assess a person's attitude, character, behavior, bad or bad organization, then the company cannot run well 5 .

\section{Work-life Policies Indicators}

According to Yu inside Hikmah, 2010) indicators that support work-life policies, namely6:

a. Occupational Health and Safety

Occupational health and safety are the most important factors in work, because without good health and safety.

b. Work relations

Strong and harmonious working relationships require careful attention to organizational communication, employee counseling and discipline.

c. Working time

Working time is very important for companies where working time becomes a milestone or a disciplinary alarm for every company or organization.

Additionally according to MCDonald and Bradley in Ganapathi \& Gilang, 2016 worklife policies that is 7 :

a. Time

Concerning an amount of time given to work and activities outside of work.

b. Involvement

The level of involvement which relates to psychological and commitment in terms of work or outside work.

c. Satisfaction

A job satisfaction in terms of carrying out a job and things that are outside of the job.

\section{Work Involvement}

To improve the results of the quality of work owned by employees, namely by having a work involvement that involves an employee's activeness or agility in carrying out tasks that have been assigned by a superior or leader to his subordinates or also

${ }^{5}$ Ludiya, H. (2016). THE EFFECT OF WORK LIFE POLICIES, WORK LIFE CONFLICT, JOB STRESS, AND LONELINESS ON TURNOVER INTENTIONS IN A. Journal of Service Management and Marketing, 9 (2), 299322.

${ }^{6}$ Hikmah. (2010). Pengaruh konflik peran ganda, kebijakan kehidupan kerja dan dukungan organisasi terhadap kinerja melalui stres kerja pada tenaga kerja wanita sektor industri di kota batam, 52-66.

${ }^{7}$ Ganapathi, I. M. D., \& Gilang, A. (2016). PENGARUH WORK-LIFE BALANCE TERHADAP KEPUASAN KERJA KARYAWAN ( STUDI PADA PT . BIO FARMA PERSERO ) THE INFLUENCE OF WORK-LIFE BALANCE ON EMPLOYEES JOB SATISFACTION ( STUDY AT PT . BIO FARMA PERSERO ), 3(1), 506-511. 
actively participating in his work. According to Robbins in HairiyahJob Involvement is a level of identification of employees in carrying out the work that has been given by the company, and the worker considers the work very important in which the work is beneficial to himself. Apart from that according to Harlie L. Reeve in Roni said that work involvement is the degree to which an employee is participating in his / her job and meetings such as prestige and autonomy. This means the extent to which employees can or can participate in the work they are assigned and fulfill all the needs that exist in the job $^{8}$.

In addition, according to Robbins and Coulter in Septian, Sintasih \& Wibawa, There are several supporting indicators for work involvement, namely:

a. Actively involved in work

Where someone is active in terms of work and takes part in completing a job sincerely and competently.

b. Shows work as the main ingredient

Prioritizing and showing work is the main thing compared to others and always tries to give the best results to the company and feels that work is something that is interesting in life and deserves to be prioritized 9 .

c. Seeing his job as something most important to self-esteem

Job involvement can be seen from a person's behavior regarding their job, where someone considers work important to their own self-esteem or can be said to focus on work without having to think about their self-esteem.

\section{Definition of Work-Family Conflict}

According to Karatepe in Erdiana \& Eviana, Work-family conflict is defined as a work load that hinders home and family responsibilities, for example by working long hours preventing an individual from attending a family gathering.

Usually this often happens to women who generally have a family where in today's era, women and men both have the same workload due to work demands that cause homework and work in the office to be neglected, that's where a problem appears. conflicts in work and family matters.

\section{Factors Affecting Work-Family Conflict (Work-Family Conflict)}

According to Bellavia and Fronce in Afrilia There are several factors that affect work-family conflict, namely:

1. Within individuals (general intra individual predictors)

2. Family Role (family role predictors)

3. Work Roles (work role predictors)

\footnotetext{
${ }^{8}$ Hairiah, L. (2017). The Influence Of Job Involvement And Job Satisfaction Toward Turnover Intention On employees Of PT.GLOBAL NIKEL MULTIGUNA TANGERANG. Jurnal Ilmiah Econosains, 15(1), 140-165.

${ }^{9}$ Septiadi, Sebastianus Alexander, Sintaasih, urged fear, \& authority, IMA (2017). WITH THE PROVIDER OF ORGANIZATIONAL COMMITMENTS Faculty of Economics and Business, University of Udayana (Unud), Bali, Indonesia.
} 


\section{Turnover Intention}

In a company, there will be a turnover intention or often referred to as someone's desire to leave the company either later or in the future, where the employee has started to feel uncomfortable working for a long time in the company due to the large number of jobs that are not organized with good. According to Lita Hariah and Roni Faslah in states that turnover intention is the tendency or intention of employees to quit their job voluntarily according to their own wishes ${ }^{10}$.

According to Tef and Meyer in (Adebayo \& Ogunsina, 2011)Turnover intention is a conscious and deliberate willingness to leave an organization. Employee turnover can be seen from how much an employee wants to leave the organization. In addition, there are several positive and negative reasons for employee turnover intention. According to Hoonakker et.al in found positive and negative reasons for employee turnover intention, which are as follows ${ }^{11}$ :

a. Positive reasons

Obtaining a higher salary and a better compensation plan than the previous place he worked, the desire to get the opportunity to learn new things, have different skills to develop a career.

b. Negative Reasons

Rewards, career planning, and development opportunities receive less attention from the company, and are linked to work and factors in the organization.

\section{Relationship between Work-Life Policies and Turnover Intention}

Employees need to be involved in making a decision. Employees can form a positive attitude towards work when the organization is committed to maintaining a good work-life balance. Where are the results of this study which shows that Worklife-Policies has a positive and significant effect on Turnover Intention. So if Worklife-Policies in PT. Sinar Bodhi Cipta Tanjungpinang increases, so Turnover Intention is also likely to increase. Relationship between Work Engagement and Turnover Intention

According to Stephen Robbins in Job involvement has a very strong relationship with employee turnover intention, because each employee has a different level of work involvement with his / her job. Where sometimes the employee can be loyal and very excited to do a job and vice versa. That statement is also in line with opinion which in his journal, low work involvement affects the desire to move in employees ${ }^{12}$.

\footnotetext{
${ }^{10}$ Yani, D. (2016). The Effect of Job Satisfaction and Job Insecurity on Turnover Intention of Teaching Staff at the Faculty of Medicine, Islamic University of North Sumatra The Influence Between Work and Job Insecurity Toward Lecturer 's Turnover Intention in Medical Faculty of Islamic, 8 (2), 79-87

${ }^{11}$ Roni, F. (2010). Relationship Between Work Involvement and Turnover Intention of Employees of PT. GARDA TRIMITRA UTAMA, JAKARTA, VIII, 146-151.

12 Hairiah, L. (2017). The Influence Of Job Involvement And Job Satisfaction Toward Turnover Intention On employees Of PT.GLOBAL NICKEL MULTIGUNA TANGERANG. Scientific Journal of Econoscience, 15 (1), 140-165.
} 


\section{Relationship between Work-Family Conflict and Turnover Intention}

According to Grondlund in stated that every woman has a demand for work where there is more workfamily conflict than the male party even in the same number of hours of work. In addition, this opinion is also related to Karatepe in which states that the higher a work family conflict or family work conflict that disturbs the family, the higher it will be, then turnover intention will occur. Where work takes a lot of time, especially overtime, so that the time given to the family is not optimal ${ }^{13}$.

\section{Framework}

Based on the theoretical basis and the formulation of research problems, the researcher identified that the independent variable $(\mathrm{X})$, namely Work-life policies, Job Involvement, and Work-Family Conflict have an effect on the dependent variable (Y), namely Turnover Intention. According to Sugiyono in his book the dependent variable is the nature or value of an object that has certain variations which have been determined to draw a conclusion. While the independent variable is a variable in which it can be estimated how many changes in the dependent variable are. So that the framework used in this study can be described as follows ${ }^{14}$.

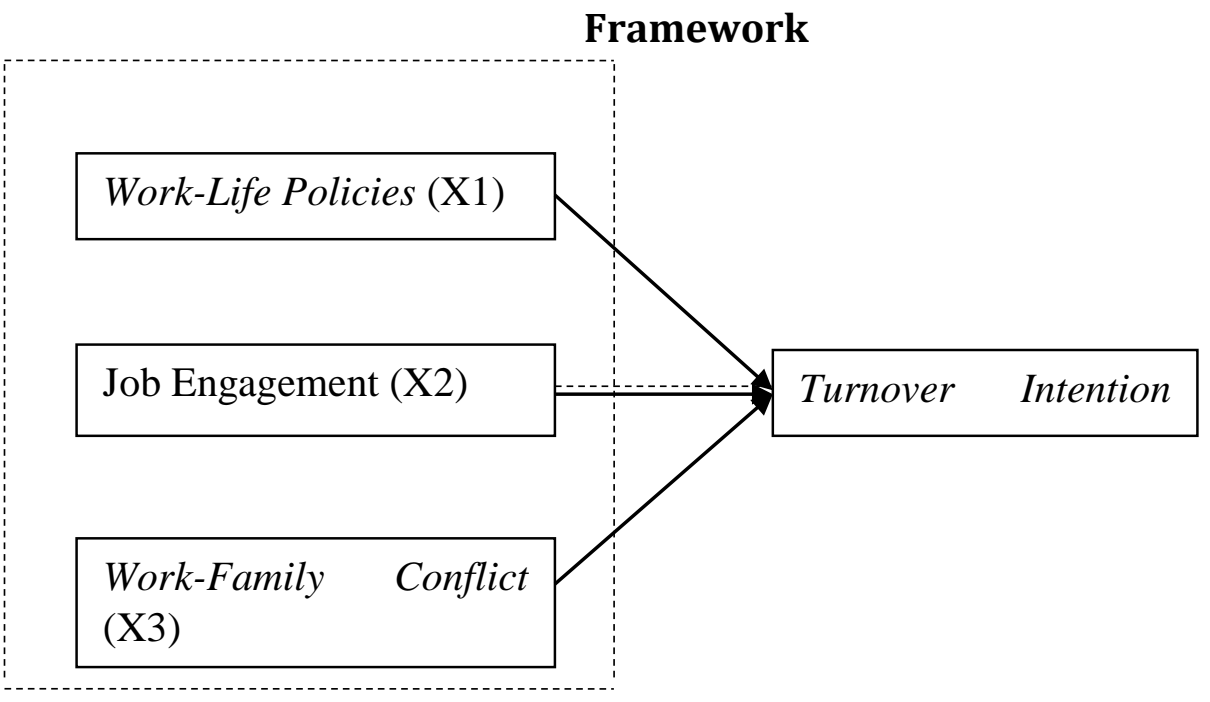

\section{Hypothesis}

Definition of a hypothesis according to Sugiono in his book is a temporary answer to the formulation of research problems, where the formulation of research problems has been stated in the form of questions. It is said temporarily, because the answers given are only based on relevant theories, not based on real facts obtained through data collection. So the hypothesis can also be stated as a theoretical answer to the formulation of the

\footnotetext{
${ }^{13}$ Erdiana, A., \& Eviana. (2012). The Effect of Work-Family Conflict on Absenteeism and Turnover Intention (a study on Employees of Banking Companies in Malang), 10,116-133.

${ }^{14}$ Sugiyono, P. (2013). Quantitative Research Methods And R \& D. In Indonesia Alfabeta.
} 
research problem, not the real answer. Based on the description of the theoretical thinking above, the hypotheses proposed in this study are ${ }^{15}$ :

H1 : work-life policiesaffect turnover intention.

H2 : job involvement has an effect on turnover intention.

H3 : work-family conflict affect turnover Intention.

H4: work-life policies, work involvement, work-family conflict affect turnover intention.

\section{RESEARCH METHODS}

\section{Types of research}

This research uses descriptive quantitative method. Where this quantitative descriptive method aims to provide an overview of society, certain groups of people. This research is quantitative in nature, namely research that solves the problem based on numbers or a conclusion can be drawn and other supporting suggestions are given. This study wanted to find a direct effect of the independent variables, namely the effect of work-life policies, work involvement, and work-family conflict on employee turnover intention at PT.SINAR BODHI CIPTA Tanjungpinang.

\section{Type of Data}

According to In his book, there are two types of data that can be used to conduct this research, namely primary data and secondary data 16

\section{a. Primary data}

Primary data is data obtained by the author through the distribution of questionnaires directly to the company, besides also making direct observations into the company. Target target and is considered to represent the entire population in the research to be examined by researchers, namely employees of PT. Sinar Bodhi Cipta Tanjungpinang.

b. Secondary Data

Secondary data is data obtained indirectly, meaning that this data is obtained by researchers using journals and a book, both of which are useful as guidelines to serve as sources of extensive research data regarding employee turnover intention.

\section{Data collection technique}

According to his book in his book, data collection techniques are carried out in several ways such as questionnaires and literature, namely:

a. Questionnaire or questionnaire

The questionnaire or questionnaire is a data collection technique that is carried out by giving a written question to the respondent about the matter to be asked so that the respondent must answer according to the list of questions that has been attached by the researcher.

\footnotetext{
${ }^{15}$ Sugiyono, P. (2013). Quantitative Research Methods And R \& D. In Indonesia Alfabeta.

${ }^{16}$ Sugiyono, P. (2013). Quantitative Research Methods And R \& D. In Indonesia Alfabeta.
} 
b. Literature

In which the author collects material that comes from various sources from books, previous research journals and other references as a theoretical basis and support in this research.

\section{Population}

Population according to in his book is a generalization area consisting of objects / subjects that have certain qualities and characteristics that are determined by the researcher to be studied and then draw conclusions. In this study the population taken was all employees of PT. SINAR BODHI CIPTA Tanjungpinang, totaling 121 employees $^{17}$.

Validity Testing

\begin{tabular}{|c|c|c|c|c|}
\hline Variable & $\begin{array}{l}\text { Question } \\
\text { Items }\end{array}$ & $\mathrm{R}$ Count & $\begin{array}{c}\text { R Table } \\
(\mathrm{df}=\mathrm{N}-2) \\
(\mathrm{df}=93-2=91)\end{array}$ & Information \\
\hline \multirow{9}{*}{$\begin{array}{c}\text { Variable } \\
\text { Worklife } \\
\text { Policies } \\
\text { (X1) }\end{array}$} & X1.WP1 & 0.763 & 0.2039 & Valid \\
\hline & X1.WP2 & 0.765 & 0.2039 & Valid \\
\hline & X1.WP3 & 0.733 & 0.2039 & Valid \\
\hline & X1.WP4 & 0.666 & 0.2039 & Valid \\
\hline & X1.WP5 & 0.673 & 0.2039 & Valid \\
\hline & X1.WP6 & 0.544 & 0.2039 & Valid \\
\hline & X1.WP7 & 0.450 & 0.2039 & Valid \\
\hline & X1.WP8 & 0.380 & 0.2039 & Valid \\
\hline & X1.WP9 & 0.703 & 0.2039 & Valid \\
\hline \multirow{10}{*}{$\begin{array}{c}\text { Job } \\
\text { Engagement } \\
\text { Variable (X2) }\end{array}$} & K1 & 0.606 & 0.2039 & Valid \\
\hline & $\mathrm{K} 2$ & 0.640 & 0.2039 & Valid \\
\hline & K3 & 0.612 & 0.2039 & Valid \\
\hline & $\mathrm{K} 4$ & 0.703 & 0.2039 & Valid \\
\hline & K5 & 0.531 & 0.2039 & Valid \\
\hline & K6 & 0.613 & 0.2039 & Valid \\
\hline & K7 & 0.585 & 0.2039 & Valid \\
\hline & K8 & 0.524 & 0.2039 & Valid \\
\hline & K9 & 0.533 & 0.2039 & Valid \\
\hline & K10 & 0.390 & 0.2039 & Valid \\
\hline \multirow{4}{*}{$\begin{array}{l}\text { Variable } \\
\text { Workfamily } \\
\text { Conflict (X3) }\end{array}$} & X3.WFK1 & 0.729 & 0.2039 & Valid \\
\hline & X3.WFK2 & 0.675 & 0.2039 & Valid \\
\hline & X3.WFK3 & 0.769 & 0.2039 & Valid \\
\hline & X3.WFK4 & 0.664 & 0.2039 & Valid \\
\hline
\end{tabular}

${ }^{17}$ Sugiyono, P. (2013). Quantitative Research Methods And R \& D. In Indonesia Alfabeta. 


\begin{tabular}{|c|c|l|l|l|}
\hline \multirow{4}{*}{} & X3.WFK5 & 0.442 & 0.2039 & Valid \\
\cline { 2 - 5 } & X3.WFK6 & 0.554 & 0.2039 & Valid \\
\cline { 2 - 5 } & X3.WFK7 & 0.566 & 0.2039 & Valid \\
\cline { 2 - 5 } & X3.WFK8 & 0.425 & 0.2039 & Valid \\
\cline { 2 - 5 } $\begin{array}{l}\text { Turnover } \\
\text { Intention (Y) }\end{array}$ & X3.WFK9 & 0.413 & 0.2039 & Valid \\
\cline { 2 - 5 } & Y.TI1 & 0.595 & 0.2039 & Valid \\
\cline { 2 - 5 } & & & & \\
\cline { 2 - 5 } & Y.TI2 & 0.524 & 0.2039 & Valid \\
\cline { 2 - 5 } & Y.TI3 & 0.439 & 0.2039 & Valid \\
\cline { 2 - 5 } & Y.TI4 & 0.802 & 0.2039 & Valid \\
\cline { 2 - 5 } & Y.TI6 & 0.627 & 0.2039 & Valid \\
\cline { 2 - 5 } & Y.TI7 & 0.654 & 0.2039 & Valid \\
\cline { 2 - 5 } & Y.TI8 & 0.619 & 0.2039 & Valid \\
\cline { 2 - 5 } & Y.TI9 & 0.812 & 0.2039 & Valid \\
\cline { 2 - 5 } & Y.TI10 & 0.820 & 0.2039 & Valid \\
\hline
\end{tabular}

There is a correlation value between the item score and the total score. Where this value will then be compared with the value of $r$ table, looking for a significance of 0.05 with a 2-sided test and the amount of data $(n)=93$ with the calculation formula looking for $r$ table $(d f=N-2)(d f=93-2=91)$, Then the $r$ table is obtained at 0.2039. Based on the results of the analysis in table 4.6 , the results obtained from testing the validity of all variables, if $r$ count $>r$ table, it can be concluded that the statement item is declared valid.

\section{Reliability Test}

After the validity test is carried out, the reliability test will then be carried out. Reliability testing in this study uses SPSS version 21, provided that if the value of cronbach's alpha> 0.06 , then the construct or variable can be said to be realistic or vice versa if the value of cronbach's alpha $<0.06$, the variable is said to be invalid. ${ }^{18}$

Reliability Testing

\begin{tabular}{|l|c|c|c|}
\hline \multicolumn{1}{|c|}{ Variable } & $\begin{array}{c}\text { Alpha } \\
\text { Calculate }\end{array}$ & $\begin{array}{c}\text { Cronbach's } \\
\text { Alpha }\end{array}$ & Information \\
\hline Worklife Policies (X1) & 0.809 & 0.60 & Realible \\
\hline Job Engagement (X2) & 0.772 & 0.60 & Realible \\
\hline Workfamily Conflict (X3) & 0.748 & 0.60 & Realible \\
\hline Turnover Intention (Y) & 0.851 & 0.60 & Realible \\
\hline
\end{tabular}

18 Sugiyono, P. (2013). Quantitative Research Methods And R \& D. In Indonesia Alfabeta. Spss version 21 
Based on table 4.11, the reliability test results show that the Worklife Policies (X1) variable has an Alpha coefficient of $0.809>0.60$, the Work Involvement Variable (X2) has an Alpha coefficient of $0.772>0.60$, the Workfamily Conflict variable (X3) has an Alpha coefficient of $0.748>0.60$, the Turnover Intention (Y) variable has an Alpha coefficient of $0.851>0.60$. Based on table 4.11, it can be concluded that it can be said that all measurement concepts for each of each variable or questionnaire statement are realistic so that they are feasible to use for measuring research tools.

\section{RESULT AND ANALYSIS Normality test}

The normality test aims to test whether the regression model, the dependent and independent variables have a normal distribution. How to detect normality is done by looking at the histogram graph in Figure 4.2 below:

\section{Histogram Graph}

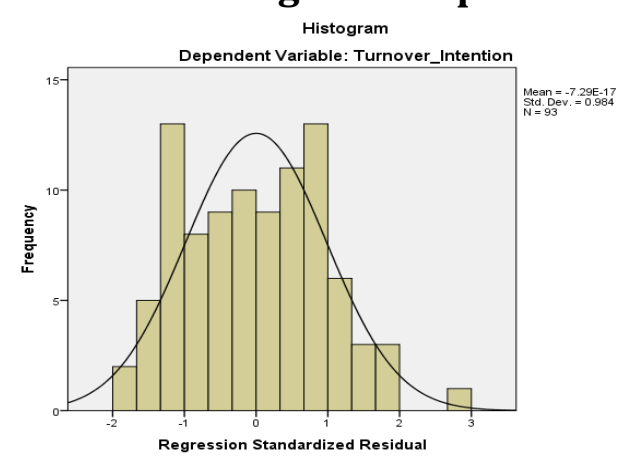

By looking at the histogram graphic display, it can be concluded that the histogram graph provides a normal distribution pattern. Because the data forms a bell-like pattern and does not veer left and right. Apart from the histogram graph, the Pp plot graph is also used to test the normality of the data. The results of the Pp plot graph were also used to test the normality of the data. The results of the Pp plot graph can be seen in Figure 4.3 below

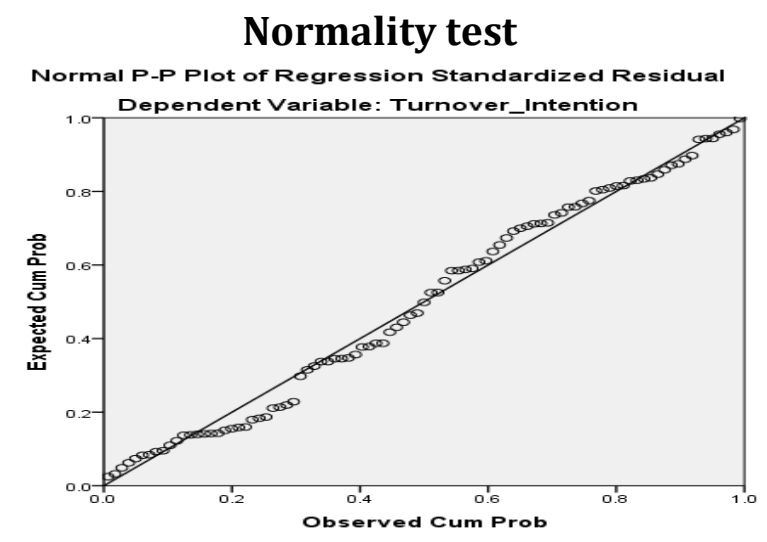

Graph display Normal Probability Plot, it can be concluded that the normal chart pattern is seen from the points that spread around the diagonal line and the distribution follows the direction of the diagonal line. Based on the histogram graph and the Normal 
Probability Plot, it shows that the regression model is suitable for use in this study because it meets the criteria for the assumption of normality.

To find out that the data really is normally distributed, a statistical test is carried out Kolmogrov Smirnov namely by looking at its value and significance. Where if the statistics and significance are greater than 0.05 , the data is normally distributed.

\section{One Sample Kolmogrov Smirnov test \\ One-Sample Kolmogorov-Smirnov Test}

\begin{tabular}{|ll|r|}
\hline & & Unstandardized Residual \\
\hline $\mathrm{N}$ & & 93 \\
Normal & Mean & .0000000 \\
Parametersa, b & Std. & \\
& Deviation & 2.38034931 \\
Most Extreme & Absolute & .076 \\
Differences & Positive & .076 \\
& Negative & .061 \\
Kolmogorov-Smirnov Z & .737 \\
Asymp. Sig. (2-tailed) & .648 \\
\hline
\end{tabular}

The results of the analysis of the one Sample Kolmogrov Smirnov method show that the Kolmogrov-Smirnov Z Test Statistic is 0.737 and a significance value of 0.0648 is greater than 0.05 , which means that the residual variables are normally distributed. In the histogram graph it can also be seen that the data distribution does not deviate from the left and right, which means that the residual variables are normally distributed.

Heteroscedasticity Test

The heteroscedasticity test aims to test whether the regression method contains inequalities and residuals from one observation to another. Good data is if there is no heteroscedasticity. Where in this study the heteroscedasticity test used a scatterplot graphic, that is, if the data spreads randomly above and below the zero on the y axis, heteroscedasticity does not occur. 


\section{Heteroscedasticity Test Results}

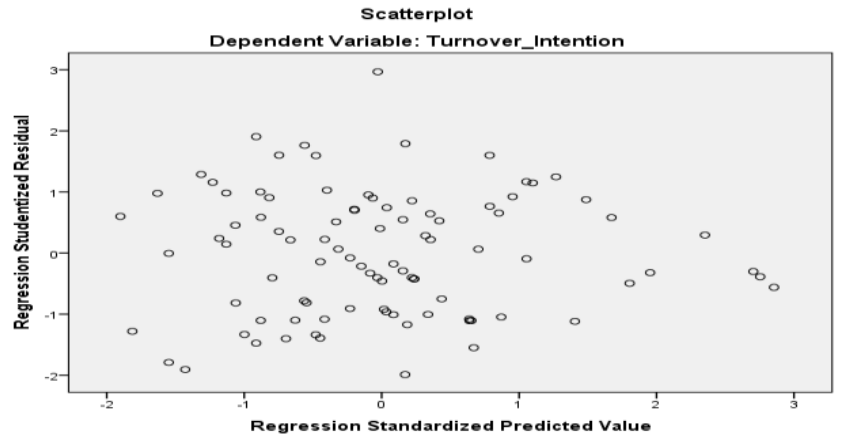

It can be seen that the dots spread randomly, not in the form of a clear pattern which is clearly spread either above or below the 0 (zero) on the $Y$ axis. It can be concluded that there is no heteroscedasticity. A good regression model is where there is no heteroscedasticity.

\section{Multicolonierity Test}

Multicolonierity test aims to test whether the regression model found a correlation between independent variables. A good regression model is one where there should be no correlation between the independent variables. In this study, the multicolonierity test was carried out by looking at the tolerance value and the variance inflation factor (VIF) value. If the tolerance value is above 0.01 and the VIF value is less than 10 , it can be concluded that the regression model does not occur multicolonierity.

\section{Multicolonierity Test Results}

Coefficientsa

\begin{tabular}{|l|r|r|}
\hline \multirow{2}{*}{ Model } & \multicolumn{2}{|c|}{ Collinearity Statistics } \\
\cline { 2 - 3 } & Tolerance & \multicolumn{1}{|c|}{ VIF } \\
\hline (Constant) & & \\
Worklife_Policies & .442 & 2,264 \\
Work_Involvement & .991 & 1,010 \\
Workfamily_Conflict & .444 & 2,251 \\
\hline
\end{tabular}

a. Dependent Variable: Turnover_Intention

It can be seen that the tolerance value for the Workfamily Policies variable is $0.442>0.1$, the tolerance value for the Workfamily Conflict variable is $0.991>0.1$, and the tolerance value for the Workfamily Conflict variable is $0.444>0.1$. For the VIF value of the Workfamily Policies variable of $2.264<10$, the VIF value of work involvement is 1.010 $<10$, the VIF value of Workfamily Conflict is $2.251<10$. So it can be concluded that in this model there is no multicolonierity problem.

\section{Autocorrelation Test}

The autocorrelation test is used to determine whether or not there is a correlation between the residuals in an observation and other observations in the regression model. The requirement that must be met is the absence of auto correlation in the regression 
model. The test method uses the Durbin-Watson test (DW test) with the following conditions:

1. If $\mathrm{d}<\mathrm{dl}$ or (4-dl), then the null hypothesis is rejected, which means there is autocorrelation.

2. If $d$ lies between du and (4-du), then the null hypothesis is accepted, which means there is no autocorrelation.

3. If $\mathrm{d}$ lies $\mathrm{dl}$ and du or where (4-du) and (4-dl), then there is no conclusion.

\section{Autocorrelation Test}

Model Summary b

\begin{tabular}{|l|c|r|r|r|r|}
\hline Model & $\mathrm{R}$ & R Square & $\begin{array}{c}\text { Adjusted R } \\
\text { Square }\end{array}$ & $\begin{array}{c}\text { Std. Error of } \\
\text { the Estimate }\end{array}$ & $\begin{array}{l}\text { Durbin- } \\
\text { Watson }\end{array}$ \\
\hline 1 & $.855 \mathrm{a}$ & .731 & .722 & 2.42014 & 1,384 \\
\hline
\end{tabular}

a. Predictors: (Constant), Worklife Policies, Work Involvement, Workfamily Conference

b. Dependent Variable: Turnover Intention

Known value Durbin-Watson 1,384. This value will be compared with the DurbinWatson test value with the Durbin-Watson value guideline with a dl value of 1.5741 and a du value of 1.7531, so it can be concluded that the Durbin-Watson value of 1.384 does not occur autocorrelation.

\section{Multiple Linear Regression Test}

Multiple linear regression analysis is usually used to measure the influence of two or more independent variables on one dependent variable. To find out the model and form of the influence relationship between variables and to determine the positive or negative influence of the independent variables (X1, X2, X3) on the dependent variable Turnover Intention $(\mathrm{Y})$ where from the sample obtained, multiple linear regression analysis is used using the following formula:

\section{$\mathrm{Y}^{\prime \prime}=\mathrm{a}+\mathrm{b} 1 . \mathrm{X} 1+\mathrm{b} 2 . \mathrm{X} 2+\mathrm{b} 3 . \mathrm{X} 3+\mathrm{e}$ \\ Multiple Linear Regression Test Results Coefficients}

\begin{tabular}{|c|c|c|c|c|c|c|}
\hline \multirow{2}{*}{\multicolumn{2}{|c|}{ Model }} & \multicolumn{2}{|c|}{$\begin{array}{l}\text { Unstandardized } \\
\text { Coefficients }\end{array}$} & \multirow{2}{*}{$\begin{array}{c}\begin{array}{c}\text { Standardiz } \\
\text { ed } \\
\text { Coefficients }\end{array} \\
\text { Beta }\end{array}$} & \multirow[t]{2}{*}{$\mathrm{t}$} & \multirow[t]{2}{*}{ Sig. } \\
\hline & & B & $\begin{array}{l}\text { Std. } \\
\text { Error }\end{array}$ & & & \\
\hline \multirow{4}{*}{1} & (Constant) & 8,499 & 3,624 & & 2,345 & .021 \\
\hline & Worklife Policies & .326 & .102 & .264 & 3,186 & .002 \\
\hline & $\begin{array}{l}\text { Work } \\
\text { Involvement }\end{array}$ & -197 & .061 & -180 & $-3,262$ & .002 \\
\hline & $\begin{array}{l}\text { Workfamily } \\
\text { Conflict }\end{array}$ & .786 & .106 & .614 & 7,437 & .000 \\
\hline
\end{tabular}


a. Dependent Variable: Turnover Intention

The results of the regression equation that are formed, as for the multiple linear regression equation as follows:

$$
\mathrm{Y}=0.8499+0.326 \mathrm{X} 1+(-0.197 \mathrm{X} 2)+0.786 \mathrm{X} 3+\mathrm{e}
$$

Where :

$\mathrm{Y} \quad=$ Turover Intention

$\mathrm{X} 1=$ Worklife-Policies

$\mathrm{X} 2=$ Work Engagement

$\mathrm{X} 3$ = Workfamily-Conflict

$\mathrm{E}=$ error $/$ confounding variable

Interpretation of the value of the equation are:

$\mathrm{Y}=0.8499$ constant value, which means that when the Worklife-Policies (X1), Work Involvement (X2), and Workfamily-Conflict (X3) variables are considered constant or do not change, the $Y$ (Turnover Intention) variable is 0.8499 .

$\mathrm{X}=0.326$ is the regression coefficient value of the Worklife-Policies variable, if the increase is one unit, then Turnover Intention (Y) will increase to 0.326 with the assumption that the work involvement variable and the WorkfamilyConflict variable are constant or do not experience a change. Likewise, on the other hand, if the Worklife-Policies variable decreases by one unit, then Turnover Intention $(\mathrm{Y})$ will decrease by 0.326 , which means that the WorklifePolicies coefficient (X1) has a positive effect on Turnover Intention (Y).

$\mathrm{X} 2=-0.197$ is the value of the regression coefficient of the job involvement variable,

If it decreases by one unit, then Turnover Intention (Y) will increase -0.197 with the assumption that the Worklife-Policies and Workfamily-Conflict variables are constant or do not experience a change. Likewise, on the other hand, if the work involvement variable increases by one unit, then Turnover Intention (Y) will decrease by -0.197 , meaning that the coefficient of work involvement (X2) has a negative effect on Turnover Intention (Y).

$\mathrm{X} 3=0.786$ is the coefficient value of the Workfamily-Conflict variable, if an increase of one unit, then Turnover Intention (Y) will increase by 0.786 assuming that the Worklife-Policies variable and constant work involvement do not experience a change. Likewise, on the contrary, if the competing Workfamily-Conflict variable decreases by one unit, then Turnover Intention (Y) will decrease by 0.786 , meaning that Workfamily-Conflict (X3) has a positive effect on Turnover Intention (Y).

\section{Hypothesis testing} Partial Regression Coefficient Test (t-test)

The $t$ test was conducted to test the regression coefficient partially from the independent variable. The results of hypothesis testing using the $t$ test can be seen from Table 4:13 


\section{Partial Test Results (t-test)}

Coefficientsa

\begin{tabular}{|c|c|c|c|c|c|c|}
\hline \multirow{2}{*}{\multicolumn{2}{|c|}{ Model }} & \multicolumn{2}{|c|}{$\begin{array}{l}\text { Unstandardized } \\
\text { Coefficients }\end{array}$} & \multirow{2}{*}{$\begin{array}{c}\begin{array}{c}\text { Standardiz } \\
\text { ed } \\
\text { Coefficients }\end{array} \\
\text { Beta }\end{array}$} & \multirow[t]{2}{*}{$\mathrm{t}$} & \multirow[t]{2}{*}{ Sig. } \\
\hline & & $\mathrm{B}$ & $\begin{array}{l}\text { Std. } \\
\text { Error }\end{array}$ & & & \\
\hline \multirow{4}{*}{1} & (Constant) & 8,499 & 3,624 & & 2,345 & .021 \\
\hline & Worklife Policies & 326 & .102 & 264 & 3,186 & .002 \\
\hline & $\begin{array}{l}\text { Work } \\
\text { Involvement }\end{array}$ & -197 & .061 & -180 & $-3,262$ & .002 \\
\hline & $\begin{array}{l}\text { Workfamily } \\
\text { Conflict }\end{array}$ & 786 & .106 & .614 & 7,437 & .000 \\
\hline
\end{tabular}

Terms:

a. $\quad \mathrm{N}=93$ (number of samples)

b. $\quad a=$ level of significance $=5 \%(0.05)$

c. The $t$ distribution table is sought at a $=5 \%: 2=2.5 \%$ (2-sided test) with degrees of freedom (df) nk-1 or 93-3-1 = 89. ( $\mathrm{n}$ is the number of samples and $\mathrm{k}$ is the number of independent variables ). With a 2 -sided test (significance $=0.025$ ) the results obtained for the $t$ table are 1.987.

Based on table 4.16, it can be seen that the results of the tests carried out partially (individual tests), the Worklife-Policies variable (X1) has a significant effect on Turnover Intention $(\mathrm{Y})$ which is indicated by a probability value of $0.002<0.05$. Furthermore, tcount 3.186> ttable 1.987, then $\mathrm{Ha}$ is accepted and $\mathrm{HO}$ is rejected, which means that the Worklife-Policies (X1) variable partially has a significant effect on Turnover Intention (Y) at PT Sinar Bodhi Cipta Tanjungpinang. Thus the hypothesis in this study can be accepted.

Based on table 4.16, it can be seen that the results of the tests carried out partially (individual tests), the Job Involvement Variable (X2) has a significant effect of $0.002<0.05$. Furthermore, tcount $-3,262>1,987$, then $\mathrm{Ha}$ is accepted and $\mathrm{H} 0$ is rejected, which means that the Job Involvement variable (X2) partially has a significant effect on Turnover Intention (Y) at PT. Sinar Bodhi Cipta Tanjungpinang. Thus the hypothesis in this study can be accepted.

Based on table 4.13, it can be seen that the results of the tests carried out partially (individual tests), Workfamily Conflict (X2) have a significant effect of $0.000<0.05$. Furthermore, tcount 7,437>1,987, then Ha is accepted and H0 is rejected, which means that the Workfamily Conflict (X2) variable partially has a significant effect on Turnover Intention (Y) at PT. Sinar Bodhi Cipta, Tanjungpinang. Thus the hypothesis in this study can be accepted. 


\section{Simultaneous Regression Coefficient Test (F-Test)}

The $\mathrm{F}$ test is performed to determine the effect simultaneously (simultaneously) of the independent variable on the dependent variable. The results of testing this hypothesis using the F-Test can be seen in the following table 4:17:

\section{Simultaneous Testing Results (Test-F)}

ANOVAa

\begin{tabular}{|rl|r|r|r|r|r|}
\hline \multicolumn{1}{|l|}{ Model } & \multicolumn{1}{|c|}{$\begin{array}{c}\text { Sum of } \\
\text { Squares }\end{array}$} & \multicolumn{1}{c|}{ df } & \multicolumn{1}{c|}{$\begin{array}{c}\text { Mean } \\
\text { Square }\end{array}$} & F & Sig. \\
\hline \multirow{2}{*}{1} & Regression & 1416,034 & 3 & 472,011 & 80,589 & $.000 \mathrm{~b}$ \\
& Residual & 521,278 & 89 & 5,857 & & \\
& Total & 1937,312 & 92 & & & \\
\hline
\end{tabular}

a. Dependent Variable: Turnover Intention

b. Predictors: (Constant), Workfamily Conflict, Job Involvement, Worklife Policies

The results of the Fcount value of 80.589 with a significance level of 0.000 with the Fcount value will be compared with the Ftable value. Ftable value at the error rate $a=5 \%$ with degrees of freedom (df) $=(n k)$ : $(k-1)$. The number of samples (n) is 93 and the number of research variables $(\mathrm{k})$ is 3 . So $\mathrm{df}=(93-3)$ : (3-1) then the value of Ftable is 2.71 . So Fcount $>$ Ftable $(80.589>2.71)$ and a significance level of 0.000 then the decision H0 is rejected, meaning that Worklife Policies (X1), Work Involvement (X2), and WorkfamilyConflict (X3) jointly (simultaneously) have an effect on Turnover. Intention (Y) at PT. Sinar Bodhi Cipta, Tanjungpinang.

\section{Determination Coefficient Test (R2)}

The coefficient of determination R2 aims to see how much influence each variable has on the dependent variable to determine the percentage of the contribution of the Worklife-Policies, Work Involvement, and Workfamily Conflict variables together on the dependent variable (Turnover Intention).

\section{Results of Testing the Determination Coefficient R2} Model Summary b

\begin{tabular}{|l|c|r|r|r|r|}
\hline Model & $\mathrm{R}$ & R Square & $\begin{array}{c}\text { Adjusted R } \\
\text { Square }\end{array}$ & $\begin{array}{c}\text { Std. Error of } \\
\text { the Estimate }\end{array}$ & $\begin{array}{l}\text { Durbin- } \\
\text { Watson }\end{array}$ \\
\hline 1 & $.855 \mathrm{a}$ & .731 & .722 & 2.42014 & 1,384 \\
\hline
\end{tabular}

a. Predictors: (Constant), Worklife Policies, Work Involvement, Workfamily Conference

b. Dependent Variable: Turnover Intention Source: Processed SPSS Data, 2018.

From table 4.18, the amount of Adjusted R2 based on the results of this study is the coefficient of determination of 0.731 which indicates that the percentage of the contribution of the influence of Worklife-Policies, Work Involvement, Workfamily- 
Conflict on Turnover Intention is $73.1 \%$. Meanwhile, $26.9 \%$ was influenced by other variables which were not examined in this study.

\section{CONCLUSION}

\section{Effect of Worklife-Policies on Turnover Intention}

Based on the results of multiple linear regression analysis, the $t$ test carried out by the Worklife-Policies variable (X1) has an effect on (Y). From the test results for the Worklife-Policies variable, it shows the tcount value of 3.186> $t$ table 1.987, with a probability value of $0.002<0.05$. Where are the results of this study(Yu, 2015)which shows that Worklife-Policies has a positive and significant effect on Turnover Intention. So if the Worklife-Policies in PT.Sinar Bodhi Cipta, Tanjungpinang increase, then Turnover Intention will also tend to increase. Where the more working hours given by the company or other matters, the more the occurrence of a Turnover Intention in an employee.

\section{The Effect of Job Involvement on Turnover Intention}

Furthermore, in the variable Job Involvement (X2) the results of the $t$ test for the work involvement variable show the value of tcount $-3.262>1.987$ with a probability value of $0.002<0.05$, it can be concluded that the Job Involvement variable has a negative and significant effect on Turnover Intention (Y). Where the results of this study are in line with research conducted by which shows that Job Involvement has a negative and significant effect on Turnover Intention. Where without there is a work involvement for the company, be it a company with a company or a company with employees, the company is not going well. So that the increasing of a Work Involvement that occurs in the company, the more the occurrence of a Turnover Intention in employees is also increased, and conversely the decreasing of a Work Involvement that occurs in the company, the decreasing the occurrence of a Turnover Intention in employees.

\section{Effect of Workfamily-Conflict on Turnover Intention}

Next on the Workfamily-Conflict variable (X3). The results of the $t$ test for the Workfamily-Conflict variable show the tcount of 7.437> 1.987 with a probability value of $0.000<0.05$, it can be concluded that the Workfamily-Conflict variable has a positive and significant effect on Turnover Intention. Where this research is in line with research that has been conducted by(Erdiana \& Eviana, 2012)where Workfamily-Conflict has a great influence on Turnover Intention. Where Workfamily ${ }^{19}$-Conflict is something that very often happens in a company where valuable time is used to gather and chat with extended families where triggers often occur between work and family. Where the increase in Workfamily-Conflict that occurs in the company, the increasing the occurrence of Turnover Intention in employees and vice versa, the decrease in Workfamily-Conflict that

\footnotetext{
${ }^{19}$ Erdiana, A., \& Eviana. (2012). The Effect of Work-Family Conflict on Absenteeism and Turnover Intention (a study on Employees of Banking Companies in Malang), 10, 116-133.

Yu, HC (2015). The Effect Of Work-Life Balance Policies on Women Employees' Turnover. Japan Society For The Promotion OF Science (JSPS) Fellow.
} 
occurs in the company, the decrease in the occurrence of Turnover Intention in employees.

\section{The Influence of Worklife-Policies, Work Involvement, and Workfamily-Conflict on Turnover Intention}

Based on the statistical test, it can be explained that the Worklife-Policies, Job Involvement, and Workfamily-Conflict competing together (simultaneously) affect Turnover Intention with a significant coefficient value. This can be proven by the value of Fcount $>$ Ftable $80.589>2.71$ with a significance of 0.000 . These results are in line with research conducted by $\mathrm{Yu}$ and Roni which states that Worklife-Policies, Work Involvement, Workfamily-Conflict have a simultaneous effect on Turnover Intention ${ }^{20}$.

\section{Conclusion}

Based on the results of research and discussion regarding Worklife Policies, Work Involvement, and Workfamily-Conflict on Turnover Intention of employees at PT. Sinar Bodhi Cipta Tanjungpinang, several things can be concluded as follows:

1. Worklife-Policies has a positive effect on Turnover Intention at PT. Sinar Bodhi Cipta Tanjungpinang. Where if the Worklife-Policies get bigger in the company, the employee turnover intention at PT Sinar Bodhi Cipta, Tanjungpinang will also increase.

2. Job Involvement has a negative effect on Turnover Intention at PT.Sinar Bodhi Cipta Tanjungpinang. Where if the Worklife-Policies decline, there will also be an increase in employee turnover intention at PT Sinar Bodhi Cipta Tanjungpinang.

3. Workfamily-Conflict positive influence on Turnover Intention at PT.Sinar Bodhi Cipta Tanjungpinang. Where if the Workfamily-Conflict gets bigger in the company, there will also be an increase in the occurrence of employee turnover intention at PT Sinar Bodhi Cipta Tanjungpinang, where many employees decide to leave the company.

4. Worklife-Policies, Work Involvement and Workfamily Conflict have a simultaneous effect on employee turnover intention at PT.Sinar Bodhi Cipta Tanjungpinang. Which means that Worklife-Policies, Work Involvement, and Workfamily Conflict together contribute to each other.

\section{REFERENCE}

A, \& Ridlo. (2012). Public Health Movement Indonesia. In PH Movement Indonesia. Surabaya: PH Movement Publication.

Adebayo, S. O., \& Ogunsina, S. O. (2011). Influence of Supervisory Behaviour and Job Stress on Job Satisfaction and Turnover Intention of Police Personnel in Ekiti State. Journal of Management and Strategy, 2(3), 13-20. https://doi.org/10.5430/jms.v2n3p13

Dharma, C. (2013). Hubungan Antara Turnover Intention Dengan Komitmen

\footnotetext{
${ }^{20}$ Roni, F. (2010). Relationship Between Work Involvement and Turnover Intention of Employees of PT. GARDA TRIMITRA UTAMA, JAKARTA, VIII, 146-151.
} 
Organisasional Di PT.X.Medan. Jurnal Ekonomi Dan Bisnis Jurusan Administrasi Niaga Politeknik Negeri Medan, 1(2), 1-98.

Edy Sutrisno, M.Si, Prof, DR, H. (2009). Manajemen Sumber Daya Manusia.

Erdiana, A., \& Eviana. (2012). Pengaruh Work-Family Conflict Terhadap Absenteeism Dan

Turnover Intention (studi pada Karyawan Perusahaan Perbankan Di Malang), 10, 116-133.

Ganapathi, I. M. D., \& Gilang, A. (2016). PENGARUH WORK-LIFE BALANCE TERHADAP KEPUASAN KERJA KARYAWAN ( STUDI PADA PT . BIO FARMA PERSERO ) THE INFLUENCE OF WORK-LIFE BALANCE ON EMPLOYEES JOB SATISFACTION ( STUDY AT PT . BIO FARMA PERSERO ), 3(1), 506-511.

Gary, S. H., \& Heather, A. (2010). The Organizational Py-Offs for Perceived Work-Life Balance Support Asia Pasific. Journal of Human Resources, 45(1), 113-123.

Hairiah, L. (2017). The Influence Of Job Involvement And Job Satisfaction Toward Turnover Intention On employees Of PT.GLOBAL NIKEL MULTIGUNA TANGERANG. Jurnal Ilmiah Econosains, 15(1), 140-165.

Halimah, T., Fathoni, A., \& Minarsih, M. (2016). LINGKUNGAN KERJA TERHADAP TURNOVER INTENTION PRAMUNIAGA Di GELAEL SUPERMARKET ( Studi Kasus Pada Gelael Superindo Kota Semarang ). Management, 2(2).

Hanafiah, M. (2014). Pengaruh Kepuasan kerja dan Ketidakamanan Kerja (Job Insecurity) dengan Intensi Pindah Kerja (Turnover) pada Karyawan PT. Buma Desa Suaran Kecamatan Sambaliung Kabupaten Berau. eJournal Psikologi, 1(3), 303-312.

Hikmah. (2010). Pengaruh konflik peran ganda, kebijakan kehidupan kerja dan dukungan organisasi terhadap kinerja melalui stres kerja pada tenaga kerja wanita sektor industri di kota batam, 52-66.

Ludiya, H. (2016). PENGARUH WORK LIFE POLICIES, WORK LIFE CONFLICT , JOB STRESS , DAN LONELINESS TERHADAP TURNOVER INTENTIONS PADA SEBUAH. Jurnal Manajemen Dan Pemasaran Jasa, 9(2), 299-322.

Lutfi Al-Khasawneh, A., Lutfi Al-khasawneh, A., \& Moh, S. (2013). The Relationship between Job Stress and Nurses Performance in the Jordanian Hospitals: A Case Study in King Abdullah the Founder Hospital. Asian Journal of Business Management, 5(2), 267-275. https://doi.org/10.5297/ser.1201.002

Muliana, Y., Aida, W., Ekonomi, F., Pengaraian, U. P., Ekonomi, F., Pengaraian, U. P., ... Pengaraian, U. P. (2016). Pengaruh Keterlibatan Kerja Dan Kepuasan Kerja Terhadap Turnover Intention Karyawan Pada PAsar Modern Pasir Pengaraian Kabupaten Rokan Hulu, 3, 1-7.

Roni, F. (2010). Hubungan Antara Keterlibatan Kerja Dengan Turnover Intention Pada Karyawan PT.GARDA TRIMITRA UTAMA, JAKARTA, VIII, 146-151.

S.P. Hasibuan Drs.H. (2017). Manajemen Sumber Daya Manusia.

Septiadi, sebastianus alexander, Sintaasih, desak ketut, \& Wibawa, I. M. A. (2017). DENGAN PEMEDIASI KOMITMEN ORGANISASIONAL Fakultas Ekonomi dan Bisnis 
Universitas Udayana ( Unud ), Bali , Indonesia Pusat Keuangan Kementerian Pertahanan Republik Indonesia merupakan badan di bawah kementerian pertahanan yang bertanggung jawab atas. Jurnal Nasional , E-Jurnal Ekonomi Dan Bisnis Universitas Udayana 6.8 (2017), 16, 3103-3132.

Sugiyono, P. (2013). Metode Penelitian Kuantitatif Dan R\&D. In Indonesia Alfabeta.

Wulansari, H., \& Yuniawan, A. (2017). ANALISIS PENGARUH WORK FAMILY CONFLICT DAN FAMILY WORK CONFLICT TERHADAP INTENTION TO QUIT DENGAN BURNOUT SEBAGAI VARIABEL INTERVENING ( Studi Pada Karyawan PT . Telekomunikasi Indonesia , Tbk . Wilayah Semarang ), 6(1985), 1-15.

Yani, D. (2016). Pengaruh Kepuasan Kerja dan Job Insecurity terhadap Turnover Intention Staf Pengajar di Fakultas Kedokteran Universitas Islam Sumatera Utara The Influence Between Work And Job Insecurity Toward Lecturer's Turnover Intention in Medical Faculty Of Islamic, 8(2), 79-87.

$\mathrm{Yu}, \mathrm{H}$. C. (2015). The Effect Of Work-Life Balance Policies on Women Employees' Turnover. Japan Society For The Promotion OF Science (JSPS) Fellow. 